\title{
THE VALUE OF BEACH NOURISHMENT TO PROPERTY OWNERS: STORM DAMAGE REDUCTION BENEFITS
}

\author{
Jeffrey J. Pompe and James R. Rinehart*
}

\begin{abstract}
This study offers a method for estimating the storm damage reduction benefits accruing to property owners from beach nourishment. We use a hedonic pricing model to estimate the increased protection value that wider beaches provide for single-family homes in two South Carolina oceanfront communities. These storm damage reduction benefits accrue not only to oceanfront property that suffers the most damage, but also to properties farther back. We find that a proposed Army Corps of Engineers' nourishment project will produce approximately $\$ 63.8$ million of cumulative benefits to owners of single-family homes, which translates into a benefit/cost ratio of 1.96 .
\end{abstract}

\section{INTRODUCTION}

With increasing numbers of people choosing seashore areas for permanent residences and vacationing, pressure is building on the government to protect eroding shorelines. ${ }^{1}$ Beach erosion is the result of natural processes such as wind, storms and global sea level rise, as well as man-made causes such as building too close to the ocean, damming rivers, and constructing jetties. Although definitive information is limited, a report by the U.S. Army Corps of Engineers found that 80 percent of the North Atlantic, Lower Mississippi, and California shorelines suffer from "significant erosion" (Platt et al. 1992). Kana (1990 p. 21) estimates that in South Carolina, where 57 miles of the State's 181 miles of ocean beach have been designated as "critically eroded," according to a 1986 Blue Ribbon Committee Report, $\$ 65$ million will be required in the 1990s alone to combat the problem. As the economic consequences of shoreline erosion become more significant, greater emphasis is placed on property protection.

Beach nourishment, a process of replenishing sand in areas that have suffered erosion, is a popular method for controlling beach loss. This study focuses on a specific beach nourishment project along the Grand Strand of South Carolina. A proposal by the U.S. Army Corps of Engineers (ACE) to nourish 5.7 miles of beach for Garden City and Surfside Beach (GC/SB) has been approved and will be implemented if funding is available in the 1995 budget. $^{2}$ The ACE is

\footnotetext{
*Assistant Professor of Economics and Professor of Economics, respectively, School of Business, Francis Marion University. The authors would like to thank the Francis Marion University Faculty Research Committee for partial funding of the project, the South Carolina Coastal Council for providing beach width measurements, and Buddy Hucks for valuable assistance with data collection. The comments of three anonymous reviewers were very helpful.
} 
required to conduct a benefit-cost study to verify that aggregate benefits exceed aggregate costs for beach nourishment projects involving any federal government funding. ${ }^{3}$ The costs of the nourishment must be justified solely by the benefits from reduced storm damage, although the ACE recognizes that there are also other gains, e.g. recreational benefits.

Since the benefits from less storm damage are not derived from transactions in the marketplace, their value must be estimated indirectly. The ACE estimates storm damage reduction benefits by estimating the value of property that likely would be destroyed from storms if no sand were added to the beach. In our study, we offer an alternative and significantly different approach to the ACE method for measuring these benefits. Specifically, we utilize a hedonic pricing model to measure the benefits to property owners from beach nourishment. These estimations are based on the "perceptions" of property owners as to the value of a wider beach, measured by their willingness to pay higher prices for homes located in proximity to wider beaches. ${ }^{4}$ It should be emphasized that our study is a preliminary effort in a topic area where there has been limited research.

\section{BEACH NOURISHMENT AND BENEFIT-COST ANALYSIS}

Since the shoreline is in constant flux due to the forces of nature and man, its contour changes continually. However, frequent attempts are made to control beach erosion, especially in areas where sprawling developments are threatened by the sea. Among the possible methods employed are "hard" shoreline protection devices such as jetties and seawalls, although serious questions have been raised regarding the wisdom of such constructions. Such devices may protect property from erosion in the immediate vicinity of the barrier, but the barrier itself tends to cause erosion of neighboring properties. For this reason new construction of most "hard" barriers is restricted. ${ }^{5}$

An alternative approach is simply to replenish beaches with sand trucked from inland or pumped from coastal areas. The cost of nourishment consists principally of the expenses associated with extracting and transporting the sand and is relatively easily computed. ${ }^{6}$ Although beach nourishment is a viable option, the practice is costly and produces benefits that are generally ephemeral. For example, Ocean City, Maryland nourished nine miles of beach during the past four years at a cost of $\$ 51.2$ million, only to see most of it washed away during the heavy storms in the fall of 1992 (Pope 1992). Estimates to cover 33 miles of New Jersey shoreline run as high as $\$ 1$ billion (Valeriano 1993).

With costs in the billions, and limited funds to pay for nourishment programs, proposals should be carefully examined in terms of cost effectiveness. ${ }^{7}$ 
Benefit-cost analysis can provide information to aid decision-makers in making proper choices. President Reagan's Executive Order 12291 on February 17, 1981, requiring federal agencies to make more extensive use of benefit-cost analysis, has made the procedure more acceptable. If benefits and costs are measured and discounted properly, all nourishment projects with benefit-cost ratios greater than one would have a viable economic justification. Without such guidelines, decisions may be biased by political interests. While benefit-cost analysis does not remove politics from the equation, it does provide some rational economic basis for the decision.

Direct benefits resulting from beach nourishment include the protection and enhancement of coastal property values for both residential and commercial owners. Although the evaluation of nourishment projects is an area of great importance to efficient policy making, relatively little research has examined the problem of measuring the protection benefits. ${ }^{8}$ Armstrong and Denuyl (1977) consider the value of alternative protection structures, such as groins or sea walls, to lakeshore property, although they do not consider beach nourishment. Brown and Pollakowski (1977) use a hedonic model to consider the implicit value of setback from a lake. Kern et al. (1980) use historical erosion rates to evaluate the impact of coastal erosion on shoreland property along the Chesapeake Bay.

Although recreational benefits for tourists and residents result from wider beaches, the ACE does not include these values in their benefit-cost analysis for project justification. Other benefits, such as increased revenues from tourists attracted by the wider beaches, also are not considered in the ACE's analysis, although some of these revenues would be included in the rents paid for oceanfront property. Since we consider only storm damage reduction benefits, the results of our study may be compared to those derived from the ACE analysis. ${ }^{9}$

\section{CALCULATING GAINS IN PROPERTY VALUES ASSOCIATED WITH WIDER BEACHES}

Our study focuses on Garden City and Surfside Beach in South Carolina. These two adjacent towns border the Atlantic Ocean and are located just south of the popular resort city of Myrtle Beach. Both localities are part of a string of beach communities comprising a 60-mile stretch of South Carolina known as the Grand Strand. Surfside, a residential development dating back to the 1950s, has about 2.1 miles of coastline, while Garden City, a locality that has had significant growth in the post-1950s, has a coastline of 4.9 miles.

In order to estimate the value of property protection afforded by a beach nourishment program, a hedonic pricing equation was estimated. ${ }^{10}$ An examina- 
tion of structural, locational, and coastal amenity characteristics provided the model variables defined in Table 1. Variables were included in the model based on theoretical justification, although some variables were dropped if they were strongly correlated with other significant variables. Based on an examination of the correlation coefficients and the stability of the model, multicollinearity between the included variables was not a problem. Although additional variables could be added to further predict housing prices (e.g., number of bedrooms), since the principle concern was to predict the value of wider beaches, we were careful to include variables that might be correlated with beach width, such as view of ocean, location on ocean, and view of inlet.

TABLE 1

Variable Descriptions and Descriptive Statistics

\begin{tabular}{|c|c|c|}
\hline $\begin{array}{l}\text { Variable } \\
\text { Definition }\end{array}$ & Mean & $\begin{array}{l}\text { Stan. } \\
\text { Dev. }\end{array}$ \\
\hline Selling Price of House & $\$ 93,677$ & 52,377 \\
\hline Age of house (years) & 13.37 & 10.08 \\
\hline Square feet of house space & 1989.30 & 840.35 \\
\hline Number of bathrooms & 2.02 & .83 \\
\hline Dummy variable ( 1 = fireplace $)$ & .19 & .39 \\
\hline Distance to nearest beach & 1785.60 & 1217.10 \\
\hline Distance to center of Myrtle Beach (miles) & 9.99 & 1.97 \\
\hline Dummy variable ( 1 = Located on oceanfront) & .09 & .28 \\
\hline Width of high tide beach (feet) & 89.40 & 23.21 \\
\hline Dummy variable $(1=$ View of ocean $)$ & .20 & .39 \\
\hline Dummy variable ( $1=$ View of inlet $)$ & .09 & .28 \\
\hline $\begin{array}{l}\text { Year of sale, } 1 \text { (Jan. 1983) to } 8 \\
\text { (Dec. 1990) }\end{array}$ & 5.22 & 2.25 \\
\hline Dummy variable ( 1 = Dock) & .06 & .24 \\
\hline $\begin{array}{l}\text { Dummy variable }(1=\text { sold after } \\
\text { Hurricane Hugo })\end{array}$ & .12 & .32 \\
\hline
\end{tabular}

Three hundred and eighty-five single family homes that were sold between 1983 and 1991 in the Garden CitylSurfside Beach communities comprise the sample. The dependent variable, i.e., the actual selling price of the house, was adjusted to 1983 prices by the national pricing index for housing. Selling price, location, and structural information, such as square footage, number of rooms and structural age, were obtained from multiple listing catalogs and county tax 
records. Distance variables were derived from various area maps, while numerous visits to the test area supplied and verified information requiring actual sight. Since Myrtle Beach is the nearest city to the sample area, this variable was included to measure the importance of nearness to a central business district. However, since Myrtle Beach is principally a resort area without the traditional city amenities, this effect would be expected to be small. A dummy variable (Hugo) was used to adjust for houses sold after Hurricane Hugo hit the area in 1989. Since Surfside and Garden City are similar in locational and neighborhood characteristics, additional proxy variables were not included. A dummy variable indicating whether a house was located in Surfside or Garden City was insignificant.

A series of 32 survey markers spaced along the shorelines of the two towns provides the high tide beach width measurements. ${ }^{11}$ Garden City beaches vary from 0 to 140 feet at high tide, and Surfside beaches vary from 57 to 119 feet. The average width of Garden City beaches was 64 feet, while Surfside City beaches average 96 feet. The nearest survey marker to a particular house serves as a measure of the beach width variable, and an indicator of the degree of the benefits from storm damage for that particular property. The beaches in this study belong to the public up to the high tideline, and do not vary in the degree of privacy afforded to property owners.

Two variables are included to adjust for the effect of beach width on housing values. To control for the recreational benefit from wider beaches, an interaction variable was created by multiplying distance from beach by high tide beach width, since including only a distance variable would not capture the widening benefits. Edwards (1989) provides a theoretical formulation showing how the implicit savings of locating farther from a beach are translated into recreational benefits for home owners. Housing prices decline as distance to the water increases, ceteris paribus, since travel cost increases and the aesthetic amenities of being near the water are lost. Studies have shown that property owners will trade lower housing prices for increased distance from a beach (i.e., increased travel cost). Thus, recreational benefits can be measured by using the distance of a house from the beach.

A second variable, high tide beach width, is included to capture the storm protection benefits. Storm surge, a rise in the ocean above normal water level, results in flooding in low areas all along coastlines. A wider beach provides added property protection from storms, benefits that are capitalized in the market price of property. Wider beaches also provide protection to property owners near to but not directly on the beach. Adjusting for the other factors that might be correlated with beach width, such as recreational benefits or ocean view, would allow the es- 


\section{TABLE 2}

Hedonic Model for Single Family Homes in

Surfside Beach and Garden City, South Carolina

$$
\mathrm{N}=385 ; \text { Adj. } \mathrm{R}^{2}=.81
$$

Dependent Variable $=$ deflated selling price of single family home $(1983 \$)$

\begin{tabular}{lcc}
\hline Variable & Coefficient & S.E. \\
Definition & -.02847 & .0103 \\
\hline Age of house (years) & .6045 & .0414 \\
Size of house (square feet) & .1299 & .0398 \\
Number of bathrooms & $.0451^{* *}$ & .0321 \\
Dummy variable $(1=$ fireplace) & -.1291 & .0188 \\
Distance to nearest beach times width of beach at high tide & .2811 & .0944 \\
Distance to center of Myrtle Beach (miles) & .2366 & .0513 \\
Dummy variable $(1=$ located on oceanfront) & .2632 & .0397 \\
Width of high tide beach (feet) & $.0894 *$ & .0494 \\
Dummy variable $(1=$ view of ocean) & .1671 & .0533 \\
Dummy variable $(1=$ view of inlet) & $-.0256 * *$ & .0263 \\
Year of sale, 1 (Jan. 1983$)$ to 8 (Dec. 1990$)$ & .1790 & .0583 \\
Dummy variable $(1=$ dock) & -.1236 & .0405 \\
Dummy variable $(1=$ sold after Hurricane Hugo) & 6.4216 & .4499 \\
Intercept & & \\
\hline All variables are significant at $1 \%$, except for: & & \\
*Significant at 10\% & ** Not significant
\end{tabular}

timation of the value that property owners place on the protection value of a wider beach.

Theory offers little direction in choosing the functional form of hedonic models, since both demand and supply influences are reflected in the reduced form equation. ${ }^{12}$ Since, a priori, functional form is unknown, the double-log functional form was determined by using the Box-Cox transformation method. ${ }^{13}$ Table 2 lists the variables, coefficients for the Box-Cox model, and standard errors. All signs are as expected, and most variables are significant at the 1 percent level. The adjusted $R^{2}$ of .81 indicates that the model predicts a substantial amount of the variation in housing prices.

Both the variable measuring beach width and the interaction variable are significant at the 1 percent level. The positive and significant relationship of beach 
width to housing prices indicates that beach nourishment increases property values. Since the model used is the double-log, the implicit price of a wider beach varies with the values of the other variables. Using the mean values of attributes for oceanfront homes, our study shows that an additional foot of sand, an increase from 79 to 80 feet, increases market value of an average house and lot by approximately $\$ 558$. However, there are diminishing returns to beach width. Increasing the width of beach from 119 to 120 feet raises market value by only \$371. Additionally, the value of wider beaches is less for homes farther removed from the beach. Using the mean values for houses $1 / 3$ of a mile from the beach, the increase in value is $\$ 234$ as the beach is widened from 79 to 80 feet, and an additional $\$ 174$ for an incremental widening from 119 to 120 feet. $^{14}$

\section{CALCULATING GAINS IN PROPERTY VALUES ASSOCIATED WITH BEACH NOURISHMENT AT SURFSIDE BEACH AND GARDEN CITY}

To illustrate the value of the model explained in the previous section, we use the ACE planned beach nourishment project as a case study. The GC/SB project proposed by the Army Corps of Engineers calls for an initial construction volume of 1.2 million cubic yards (cy) of sand, with a periodic nourishment of 280,000 cy, with all sand for the project taken from offshore ocean sites (U.S. Army Corps of Engineers, 1993). This will add 30 cy per linear foot of sand, creating a 10foot-wide berm at an elevation of 7 feet above National Geodetic Vertical Datum. ${ }^{15}$ This will widen the high tide beach by an average of approximately 107 feet in Surfside Beach and by 89 feet in Garden City. ${ }^{16}$ Estimated initial cost is $\$ 11,532,000$, with periodic nourishment costs of approximately $\$ 21$ million over the next 50 years. Total costs of the project are expected to be about $\$ 32.5$ million.

The ACE bases its estimates of storm damage reduction benefits on a comparison of the anticipated erosion and storm damage that would occur with and without the nourishment. For the GC/SB project, they estimate that property approximately 330 feet beyond the mean high water line will be damaged if the project is not implemented. Based on an appraisal of the market value of the structures that would be damaged, they estimate the cumulative damage to be $\$ 137,130,000$. This figure includes residential and commercial property as well as public infrastructure such as roads. Based on these calculations, the benefit-cost ratio is determined to be 4.2 .

An alternative estimation of storm damage protection benefits can be made with the model from our study. Since the value of a wider beach can be seen as a 
TABLE 3

Value of Beach Nourishment for Average House

at Different Distances from Beach

(in 1983 dollars)

\begin{tabular}{lcc}
\hline \hline & $\begin{array}{c}\text { Surfside } \\
\text { Beach }\end{array}$ & $\begin{array}{c}\text { Garden } \\
\text { City }\end{array}$ \\
\cline { 2 - 3 } $\begin{array}{c}\text { Distance } \\
\text { from }\end{array}$ & $\begin{array}{c}\text { Beach Width } \\
\text { Increased from } 98 \text { to } \\
\text { Beach (miles) }\end{array}$ & $\begin{array}{c}\text { Beach Width } \\
\text { Increased from } 73 \text { to } \\
169 \text { feet }\end{array}$ \\
\hline Oceanfront & $\$ 27,410$ & $\$ 41,246$ \\
0.10 & 20,887 & 26,669 \\
0.25 & 16,555 & 25,708 \\
0.50 & 14,493 & 12,877 \\
0.75 & 12,205 & - \\
\hline
\end{tabular}

stream of benefits over the years in the form of less property value loss, the value of a wider beach is capitalized in housing prices. Using the model from Table 2, a wider beach value resulting from nourishment can be estimated (see Table 3 ). The mean value of other attributes from the model in Table 2 is used. For estimation of the nourishment benefit, we use the average high tide beach width of 73 feet for Garden City and 98 feet for Surfside Beach, based on the 1989 readings. The beach nourishment project, which adds 107 feet of beach width in Surfside Beach, increases the value of the average oceanfront home by $\$ 27,410$. For Garden City the addition of 96 feet increases the value of the average oceanfront home by $\$ 41,246 .{ }^{17}$ Table 3 summarizes the value to an average house in Surfside Beach and Garden City at different distances from the beach. The model also indicates that the nourishment project adds substantial value to houses removed from the oceanfront, benefits not calculated by the ACE method.

The aggregate benefits to Surfside Beach and Garden City in terms of property protection can be estimated by summing the increased benefits to all single-family homes in the area. There are approximately 2300 single-family homes in Surfside Beach and 1000 single-family homes in Garden City. Multiplying the values in Table 3 by the number of houses at different distances shows estimated cumulative benefits of the nourishment project for single-family homes to be $\$ 63,779,417$, which produces a benefit/cost ratio of $1.96 .^{18}$

Although the ACE estimates recreational benefits separately from damage reduction benefits, ${ }^{19}$ it should be noted that since housing market prices are used in their estimations, property values also reflect the level of recreational benefits. Therefore, the ACE estimations, which are based on the market value of housing 
that will be destroyed, include some double counting of recreational benefits. While including recreational benefits is defensible if only damage reduction benefits are to be estimated, the values have an upward bias. The hedonic model used in our study controls for recreational benefits by using the interaction variable of distance to beach times beach width. This approach allows the beach width variable to measure only storm damage benefits.

Our estimate of damage reduction benefits is superior to the one currently used by the ACE. Certainly there is protection value from nourishment to property near the ocean, but there is also storm protection for property farther removed from the sea, a benefit not currently measured by the ACE. The hedonic model allows this value to be calculated. Our approach is also based on more realistic assumptions. It is unlikely that property owners would allow property to be completely destroyed, but instead would practice damage avoidance, for example by strengthening and elevating buildings. The ACE analysis assumes, however, that if the beach is not nourished, all property value will be lost.

\section{POLICY ISSUES}

The SBIGC nourishment project, as well as numerous other projects handled by the U.S. Army Corps of Engineers, is to be paid for by federal, state, and local governments. Our model illustrates that ocean area property owners enjoy significant benefits from beach nourishment, paid for with public dollars, and much of that comes from taxpayers living in other parts of the state and country. Of course, some of the benefits accruing to property owners are passed on to the government in the form of higher taxes.

The benefit-received principle of taxation would suggest that the beneficiaries of a project should bear the costs. Seabrook Island, a private development on the Atlantic Ocean south of Charleston, South Carolina, is a good example of this principle in operation. Since the Island allows no public access, the residents must bear all beach nourishment expenses, unlike other coastal communities where beaches are public, thereby qualifying the locality for government money. Property is assessed (and owners know this in advance) for annual beach maintenance. Beachfront properties, as expected, are assessed the most, while properties not on the beach are assessed reduced amounts that vary according to category, such as whether they are villas, homes or unimproved lots. The authors are presently engaged in a study of Seabrook Island's beach nourishment program in an attempt to see how close their tax assessments for nourishment match the property value gains predicted by our hedonic model. 
Our study identifies property owners as major beneficiaries of beach nourishment, with those located on the ocean benefiting the most. Further, the model provides a basis for determining the value to a specific property from beach nourishment, and therefore, could provide a method for estimating the appropriate tax to be charged, not only for beachfront properties but for those removed from the ocean. Clearly, an oceanfront house should be assessed more than an identical house 1/4 mile from the beach, and the latter more than one 1/2 mile away, and all three more than a property 500 miles from the ocean. A tax contour map, similar to the ones that are used to estimate the rates of flood insurance premiums, could be developed. Of course, the cost of beach nourishment should also be shared with other beneficiaries, e.g. recreational beach users.

Black et al. (1990) compare land values and use the judgment of realtors to estimate the value of beachfront houses to be $\$ 60,000$ greater with a nourishment program for South Bethany, Delaware, beaches. They suggest a special assessment on beach properties, since much of the nourishment benefit accrues to those property owners. Since the property owners gain significantly, this type of tax is desirable from an equity perspective. Such an assessment could be administered along with the local property tax in exactly the same way we presently charge taxpayers for schools, debt, retirement, libraries, etc. Since potential property owners would know of these assessments, infringement of property rights should not be an issue. Of course the tax assessment would impact negatively on property prices, as the tax is capitalized into the value of the property. Where beach nourishment taxes are in place, which is not the case for Garden City and Surfside Beach, our model would need to be adjusted for this fact.

\section{SUMMARY AND CONCLUSIONS}

This study provides a method of estimating storm damage reduction benefits to property owners of single-family homes arising from beach nourishment projects. Such benefit computations would assist policymakers in determining the desirability of beach nourishment and would aid in the assignment of costs. This aspect of coastal zone management has not received much attention, and our model provides valuable insights. Since this is a first attempt at using the hedonic technique for beach nourishment values, further examination of other project areas would be desirable.

We offer an alternative method of determining the value of beach nourishment that is significantly different from current techniques. While the Army Corps of Engineers estimates benefits by measuring the amount of property damage if a nourishment project is not undertaken, the hedonic pricing model es- 
timates the increased protection value the wider beach actually provides for a property owner. Such information, if properly utilized, could go far in establishing an equitable tax plan for paying for the nourishment cost. Moreover, this study shows that in addition to benefits accruing to beachfront property owners, significant benefits, not calculated by current ACE methods, also are created for property owners not directly on the ocean. ${ }^{20}$

Beaches are an extremely valuable resource, and a resource that will increasingly require attention, some of which will be in the form of beach nourishment. Comparison of the incremental benefits and costs of various nourishment projects at a given beach would help planners decide the appropriate scope of their nourishment efforts. If such benefit-cost projections were available for selected beaches along a given coastline, a more efficient allocation of beach nourishment funds among beaches is also likely. Although additional data and analysis are required for a complete assessment of such policies, our methodology provides an important framework that is useful for further analysis.

\section{ENDNOTES}

1. From 1940 to 1988 , the number of people in the United States living within 50 miles of the coastline went from 61 to 130 million (Long 1990, p. 6), representing an increase from 46 percent of the U.S. population in 1940 to 53 percent in 1988.

2. This project is part of a larger project that will also nourish two other areas of the Grand Strand north of the Garden City/Surfside area for an additional 17 miles. However, we consider only the GC/SB portion of the project.

3. The Federal government will pay for 65 percent of both the initial construction cost and the periodic maintenance cost.

4. The estimates of the value of wider beaches may be biased downward, since the federal government subsidizes some coastal flood insurance, as well as providing emergency aid in times of natural disasters such as hurricanes.

5. Beach erosion at Folly Beach, South Carolina, is an example of erosion caused by jetties. Although the jetties have protected Charleston harbor for shipping interests, serious erosion problems have resulted on Folly Beach. See Platt, et al. (1991) for an excellent discussion of the problem.

6. Costs for South Carolina beaches have been estimated by Kana to range from $\$ 1$ to $\$ 2$ per cubic yard for sand pumped or scraped from accreting zones to nearby eroding zones, and from $\$ 5$ to $\$ 10$ per cubic yard for inland or offshore sand (Kana 1990, p. 39). 
7. There may also be significant environmental costs such as further erosion and loss of wildlife habitat caused by the removal of sand bars, that need to be considered. For the particular project examined in our study, this does not seem to be the case.

8. Parsons and Wu (1991), although they do not consider the value of beach width, use a hedonic model to examine the value of amenities (e.g., view of water, frontage on water, and nearness to water) to coastal housing. They determine the value of these lost benefits resulting from restrictive land use controls.

9. The ACE measures some storm damage reduction benefits that are not included in our study. See endnote 18 for further discussion of this point.

10. Although the hedonic method has been widely used in numerous applications, caution should be used when making policy decisions. Various studies have pointed out weaknesses in the hedonic technique, such as biased estimates of willingness to pay (Bartik, Butler, Liu, 1991). For a detailed discussion of hedonic models, including some of the problems of estimation and necessary conditions, see Freeman (1993).

11. All survey marker readings were provided by the South Carolina Coastal Council for Spring 1989.

12. Various functional forms for the hedonic model have been proposed, including the linear, the quadratic, the log-log, semi-log, and Box-Cox transformation. For example, although Cassel and Mendelsohn (1985) have misgivings about the ability of the quadratic Box-Cox function to measure marginal implicit prices, Rasmussen and Zuehlke (1990) find that the semi-log quadratic model is useful for policy applications.

13. For the hedonic price equation, the following Box-Cox model, where $\alpha$ and $\beta$ are the unknown Box-Cox transformation parameters, was estimated using a maximum likelihood algorithm:

$$
P^{(\alpha)}=a_{o}+\Sigma a_{i} h_{i}^{\beta}+\Sigma a_{j} D_{j}
$$

where:

$$
\begin{aligned}
\mathrm{P}^{(\alpha)} & =\left(\mathrm{P}^{\alpha}-1\right) / \alpha & & \text { when } \alpha<0 \\
& =\ln \mathrm{P} & & \text { when } \alpha=0 \\
h_{i}^{\beta} & =\left(h_{i}^{\beta}-1\right) / \beta & & \text { when } \beta \\
& =\beta \operatorname{lnh} h_{i} & & \text { when } \beta=0
\end{aligned}
$$

Because different parameters for each independent variable $\left(\mathrm{h}^{\mathrm{i}}\right)$ are expensive to compute, $\beta$ was given the same value for each $h$. Dichotomous variables are not transformed. Iterations were performed for $\alpha$ and $\beta$ over the interval -1.00 to 1.00 by increments of 0.1 . The optimal values for the Box-Cox form were $\alpha=0$ and $\beta=0$, so that the double-log model was chosen. 
14. As expected, the interaction variable, the product of beach width and distance to beach, is negative, so that the effect of a wider beach is decreased for houses farther from the beach.

15. National Geodetic Vertical Datum is approximately the same as mean sea level.

16. Since the 107 -foot increase in beach width will extend some beach width measures beyond the range of width values in the study, the estimates of beach values should be viewed with some caution.

17. The average price of an oceanfront home in Garden City and Surfside Beach from our sample is $\$ 171,360$ and $\$ 166,860$, respectively.

18. The hedonic model in this study considers only single-family homes so that value to commercial property, condominiums, or multi-family homes would be additional to our estimated values. Based on conversations with the ACE, we estimate that approximately $\$ 32,636,000$ in cumulative storm damage reduction benefits can be attributed to single-family homes in their study, which includes only oceanfront homes.

19. Using the travel cost method, the ACE estimates the average annual recreational benefits from the nourishment to be $\$ 2,296,000$. As noted earlier, these values are not included in project justification.

20. The results of this model may be sensitive to characteristics peculiar to the Grand Strand area. For example, to the extent that the wider beach premium is due to storm protection benefits, property owners in coastal areas that are not prone to the same storm damage as the Grand Strand would have significantly lower or higher valuations of a wider beach. The probability of a hurricane hitting the South Carolina coast is one every 25 years. Northeasterners, which are more frequent, can also cause severe erosion and flooding, especially if they occur during full moon tides (Appendix 1, SCBMA).

\section{REFERENCES}

Armstrong, J. M., and R. B. Denuyl. "An Investment Decision Model for Shoreland Protection and Management." Coastal Zone Management 3, no. 3 (1977): 237-253 .

Bartik, T. J., Butler, J. S. and Liu, J. "Maximum Score Estimates of the Determinants of Residential Mobility: Implications for the Value of Residential Attachment and Neighborhood Amenities." Journal of Urban Economics, 32 (1991): 233-256. 
Black, D. E., L. P. Donnelley, and R. F. Settle. Equitable Arrangements for Financing Beach Nourishment Projects. Ocean and Shoreline Management 14 (1990): 191-214.

Box, G. E., and D. R. Cox, "An Analysis of Transformations." Journal of the Royal Statistical Society, 26 (1964): 211-43.

Brown, G. M., and H. O. Pollakowski. "Economic Valuations of Shoreline." Review of Economics and Statistics, 59 (1977): 272-278 .

Cassel, E., and R. Mendelsohn. "The Choice of Functional Forms for Hedonic Price Equations: Comment." Journal of Urban Economics 18 (1985): 135142.

Edwards, S. F. "On Estimation Household Demand for Outdoor Recreation From Property Values: An Exploration." Northeastern Journal of Agricultural and Resource Economics, 18 (1989): 229-40.

Edwards, S. F., and F. J. Gable. "Estimating the Value of Beach Recreation From Property Values: An Exploration With Comparisons to Nourishment Costs." Ocean and Shoreline Management: (1991): 37-55.

Freeman, A. M. The Measurement of Environmental and Resource Values: Theory and Methods. Washington, D.C.: Resources for the Future. (1993).

Kana, T. W. Conserving South Carolina Beaches Through the 1990s: A Case for Beach Nourishment. Charleston, SC: South Carolina Coastal Council (1990). Kern, W. R., R. J. Byrne, and C. H., Hobbs. "An Economic Strategy for Management of Shoreline Erosion." Coastal Zone Management Journal 8, no. 2 (1980): 165-184.

Long, L. "Population By the Sea." Population Today April (10): 6-8 (1990).

Parsons, G. R., and Y. Wu. "The Opportunity Costs of Land-Use Controls: An Empirical Analysis." Land Economics, 67 (1991): 308-16.

Platt, R. H., T. Beatly, and H. C. Miller. "The Folly at Folly Beach and Other Failings of U.S. Coastal Erosion Policy." Environment v. 33, 9 (1991): 6-9, 25-32.

Platt, R. H., T. Beatly, H. C. Miller, J. Melville, and B. Methenia. Coastal Erosion: Has Retreat Sounded. University of Colorado: Institute of Behavioral Sciences (1992).

Pope, C. Coastal Clashes. The State Newspaper. Columbia, SC. November 22, 1992.

Rasmussen, D. W., and T. W. Zuehlke. "On the Choice of Functional Form for Hedonic Price Functions." Applied Economics 22 (1990): 431-438.

Rosen, S. "Hedonic Prices and Implicit Markets: Product Differentiation in Pure Competition." Journal of Political Economy. 82 (1974): 34-55 .

South Carolina Beachfront Management Act. SC 49-39-10 (1988). 
South Carolina Blue Ribbon Committee on Beachfront Management. Report. Charleston, SC (1987).

U.S. Army Corps of Engineers. General Design Memorandum: Myrtle Beach, South Carolina Shore Protection Project. Charleston, SC (1993).

Valeriano, L. Wall Street Journal. March 18, 1993. 